DR. MARÍA C. NALLY (Orcid ID : 0000-0003-3885-5621)

Article type : Original Article

\title{
Evaluation of behavior of Lachancea thermotolerans biocontrol agents on grape
}

fermentations

Nally María Cristina ${ }^{* 1, a, d}$, Ponsone María Lorena ${ }^{1, c, d}$, Pesce Virginia Mercedes ${ }^{\mathrm{a}, \mathrm{d}}$, Toro María Eugenia $^{\mathrm{a}}$, Vazquez Fabio ${ }^{\mathrm{a}}$, Chulze Sofía ${ }^{\mathrm{b}, \mathrm{d}}$

Short running head: Biocontrol Lachancea behavior

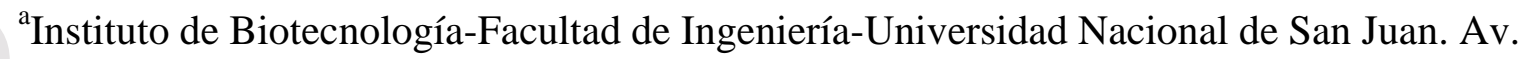

Libertador San Martín 1109 oeste (5400). Capital, San Juan, Argentina.

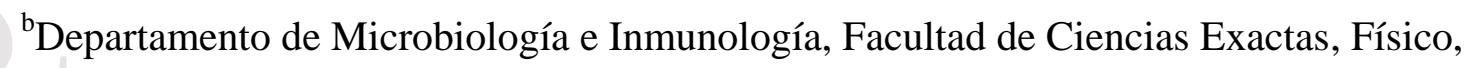
Químicas y Naturales-Universidad Nacional de Río Cuarto-Ruta Nacional №36 Km 601 (5800)-Río Cuarto, Córdoba-Argentina.

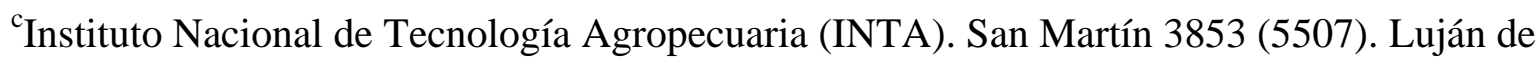
Cuyo, Mendoza, Argentina.

This article has been accepted for publication and undergone full peer review but has not been through the copyediting, typesetting, pagination and proofreading process, which may lead to differences between this version and the Version of Record. Please cite this article as doi: 10.1111/lam.13001

This article is protected by copyright. All rights reserved. 
${ }^{\mathrm{d}}$ Consejo Nacional de Investigaciones Científicas y Técnicas (CONICET)-Av.Rivadavia 1917 (C1033AAJ)-Buenos Aires-Argentina.

*Corresponding author. Tel:+542644211700; fax:+542644213672.

E-mail address: cristinanally@yahoo.com.ar (M.C.Nally).

\section{${ }^{1}$ Equal contribution}

\section{SIGNIFICANCE AND IMPACT OF THE STUDY}

Generally it is not evaluated if the biofungicide yeasts sprayed on vegetables alter the quality of the fermented products. This work focused in the importance of assessing the possible effects of fungicides based on yeasts used in vineyards on grape fermentative, especially on S. cerevisiae growth. In this context, the competition between biofungicide yeasts and $S$. cerevisiae under winemaking conditions will be investigated.

\section{ABSTRACT}

In previous researches, $L$. thermotolerans RCKT4 and RCKT5 were showed that inhibited Aspergillus growth. However, currently there are no data about their nutritional preferences, as a possible substrate competitor against $S$. cerevisiae, and their effects on fermentative process. In the present work we observed that the biocontrol yeasts and S. cerevisiae BSc203, based in the utilization of 16 carbonate sources, reveled significantly differences in the nutritional profile (biocontrol yeasts NS:0.25, BSc203 NS:0.56). L. thermotolerans strains did not occupy the same niche that BSc203 (NOI:0.44). The biocontrol agents and BSc203 presented similar competitive attitude in terms of the sugar, ethanol, and sulphite tolerances. In fermentative conditions, the biocontrol yeasts found to tolerate until 12\%v/v ethanol, 
$250 \mathrm{mg} \mathrm{ml}^{-1}$ of total $\mathrm{S}_{2}$ and $30^{\circ}$ Brix sugar. In mixed cultures, L. thermotolerans strains did not negatively affect BSc203 growth and the wine quality, except when RCKT4 was initially inoculated at a high proportion in the mixed culture 1MSK4 (1\%BSc203/99\%RCKT4), resulting in a lower production of $\mathrm{CO}_{2}$ and ethanol, in comparison with $\mathrm{BSc} 203$ pure. RCKT5, at a high proportion in 1MSK5 (1\%BSc203/99\%RCKT5), presented promising oenological properties. This fermentation showed lower acetic acid contents and higher total acidity than pure BSc203.

Keywords: L. thermotolerans, biocontrol, S. cerevisiae, substrate competition, behavior, fermentations.

\section{INTRODUCTION}

Grapes are susceptible to fungal diseases, especially grey rot, downy mildew and black rot (Covarelli et al., 2012). Conventional approaches to fungal control have focused on chemical applications. However, sole reliance on this approach is not sustainable because of the emergence of fungicide resistance in vineyards (Leroch et al., 2011) and the adverse effects of chemical pesticides on the environment and human health (Komárek et al., 2010). A biological approach is highly desirable to control fungal growth on grapes, as this would help to reduce the amount of agrochemical residues on grape, wine and related products (Cabras and Angioni, 2000). Among the various potential antagonists, yeasts have been studied as fungal biocontrol agents on grapes (Nally et al., 2012; 2013; Calvo- Garrido et al., 2013; Ponsone et al., 2011; 2016). The major mode of action of these yeasts is the competition for nutrient and space (Nally et al., 2015). Few data have been published about the influence of yeast-based biofungicide used in vineyards on grape fermentative process (Calvo-Garrido et al., 2013; Guzzon et al., 2014). Generally it is not evaluated if the antifungal yeasts sprayed on vegetables alter the quality of the fermented products, and if these microorganisms

This article is protected by copyright. All rights reserved. 
continue competing for nutrients and space, especially with S. cerevisiae in fermentative process.

Some investigators have been reported that strains belonging to L. thermotolerans specie have been increased the acidity (Kapsopololus et al., 2007; Balikci et al., 2016), the aroma complexity (Escribano et al., 2018) or secondary ones as biogenic amines reduction (Benito et al. 2015), aroma complexity (Escribano et al., 2018) or reduction in anthocyanin loses during fermentation (Benito et al. 2018).

Ponsone et al. $(2011,2016)$ found that two L. thermotolerans strains, RCKT4 and RCKT5, increased the lag phase, diminished the in vitro growth rate of Aspergillus and also decreased OTA accumulation in wine grapes. The use of biofungicide Lachancea yeasts in vineyards produce wine without presence of mycotoxins. However, it is unknown if these microorganisms affect the fermentative process. Previous investigations reported that some non-Saccharomyces were capable to persist throughout the fermentation process and compete with Saccharomyces for nutrients, causing a fermentative stuck (Fleet and Heard, 1992; Bisson, 1999). Because there is little information about the oenological behavior of biofungicide yeasts during grape fermentations, the aims of this study were: 1-To evaluate the competition for nutrients between biocontrol yeasts and S. cerevisiae: Nutritional size (NS), Niche Overlap index (NOI). 2-To evaluate behavior of biocontrol yeasts in fermentative conditions: $\mathrm{SO}_{2}$, ethanol, sugar tolerances, effects on $\mathrm{BSc} 203$ growth, persistence time and wine quality in mixed cultures Biofungicide/Lachancea.

This article is protected by copyright. All rights reserved. 


\section{RESULTS AND DISCUSSION}

\section{Nutritional and oenological behavior of L. thermotolerans RCKT4 and RCKT5.}

\section{Nutritional Size (NS) and Niche overlap index (NOI)}

The two biocontrol yeasts assimilated the same carbon sources in vitro. From 16 carbon sources tested, 4 were utilized by RCKT4 and RCKT5 (NS:0.25), and 9 were utilized by $S$. cerevisiae BSc203 (NS:0.56) (Table 1). Glucose, sucrose, raffinose and arginine were used by all the yeasts strains tested. Proline, asparagine, alanine, fructose and melibiose were used only by BSc203. The biocontrol strains did not occupy the same ecology niche than BSc203 (NOI:0.44), showing a low level of competence between biocontrol yeasts and BSc203

(Table 1). These results suggested that biocontrol strains were not able to successfully assimilate a wide variety of nutrients of the wine grape, making them available to BSc203. The NOI between yeast-filamentous fungi (La Penna et al., 2004; Nally et al., 2015), bacteria-bacteria (Jaspers and Overmann, 2004) and bacteria-filamentous fungi (Nesci et al., 2005) have been previously studied. There is only one publication about the NOI between yeasts the same genera (Janisiewicz, 1996). At present, this work provides new data on NOI between yeasts isolates from grape musts which belong to different genera.

\section{Tolerances to $\mathrm{S0}_{2}$, sugar and ethanol}

In the present study it was observed that biocontrol yeasts were able to ferment in media with 25 to $250 \mathrm{mg} \mathrm{l}^{-1} \mathrm{SO}_{2}$, but they were unable to ferment in media with $300-400 \mathrm{mg} \mathrm{l}^{-1} \mathrm{SO}_{2}$ (Table 2). Comitini et al. (2011) showed that L. thermotolerans isolates assayed were less resistant to $\mathrm{SO}_{2}$ than $\mathrm{RCKT} 4$ and $\mathrm{RCKT5}$. These strains did not ferment grape musts with 20- 
$30 \mathrm{mg} \mathrm{l}^{-1} \mathrm{SO}_{2}$. The discrepancy between results may be explained by differences in the concentration of extracellular acetaldehyde (Nadai et al., 2016; Stanley et al., 1993).

RCKT4 and RCKT5 were able to tolerate high ethanol (7-11\%v/v) and sugar (21 and 30 Brix) levels (Table 2). Levels of ethanol tolerance in the present study exceeded values reported by Kapsopoulou et al. (2005), who observed that $L$. thermotolerans strains did not tolerate must with 9\%v/v ethanol. Gobbi et al. (2013) mentioned that L. thermotolerans presented a high fermentation power $(10.46 \%)$ too. The discrepancy between results on tolerances may be explained by differences in the plasma membrane fluidity, integrity of strains assayed (Henderson and Block, 2014) or by the strain variability in the fermentations power (Comitini et al., 2011).

In general, the biocontrol agents and BSc203 presented similar competitive attitude in terms of the sugar, ethanol, and sulphite tolerances. The current study is the first that provides data on tolerance of $L$. thermotolerans biocontrol agents to ethanol, sugar and $\mathrm{SO}_{2}$ concentrations under winemaking conditions.

\section{Impact of L. thermotolerans strains on S. cerevisiae BSc203 and on the wine quality} In pure cultures, viable cells of RCKT4, RCKT5 and BSc203 were present until the end of the fermentations (22d) (Figure 1 A, B). In biocontrol/BSc203 co-cultures, the survival time of RCKT4 and RCKT5 depended on the biocontrol strain used, and the initial ratio of the yeasts assayed. In general, RCKT4 persisted more time than RCKT5. In the RCKT4/BSc203 co-cultures, RCKT4 was detected until day 5 (3MSK4), 11 (2MSK4) and 12 (1MSK4)

(Figure 1A). RCKT5 was detected until day 2 (3MSK5), 8 (2MSK5) and 10 (1MSK5)

(Figure 1B). Analyzing investigations, cell viability of L. thermotolerans (indicated as L.t.) in mixed cultures with S. cerevisiae (indicated as S.c.) was different. In 50\%L.t.-50\%S.c. mixed culture, L.t. disappeared in day 7 (Kapsopoulou et al., 2007), 15 (Comitini et al., 
2011), and 17 (Ciani et al., 2006). In mixed 90\%L.t.-10\%S.c., L.t. was present until day 22 (Gobbi et al., 2013); and in 99\%L.t.-1\%S.c. co-culture; L.t. was present during 22 days (Comitini et al., 2011). The discrepancy about survival time of L. thermotolerans in mixed cultures with $S$. cerevisiae may be to the different initial sugar concentration of the medium used to perform the fermentative assays (between 16 and 27\% of sugar). This showed an important notion of how media and the characteristics of the yeast strains may predetermined the selection of them.

In RCKT4/BSc203 mixed cultures, BSc203 reached its maximum cell population on day 4 in 3MSK4 (7.65 $\left.\log _{10} \mathrm{CFU} \mathrm{ml}{ }^{-1}\right)$ and $2 \mathrm{MSK} 4\left(7.59 \log _{10} \mathrm{CFU} \mathrm{ml}{ }^{-1}\right)$, and on day 6 in 1MSK4 $\left(6.44 \log _{10} \mathrm{CFU} \mathrm{ml}{ }^{-1}\right.$ ) (Figure 2A). These values were similar to a culture pure BSc203 (7.69 $\log _{10} \mathrm{CFU} \mathrm{ml} \mathrm{m}^{-1}$ on day 3), except for 1MSK4. In BSc203/RCKT5 mixed fermentations, BSc203 reached a maximum cell density: on day 4 in 3 MSK5 $\left(7.68 \log _{10} \mathrm{CFU} \mathrm{ml}{ }^{-1}\right)$ and 2MSK5 (7.76 $\left.\log _{10} \mathrm{CFU} \mathrm{ml}{ }^{-1}\right)$, and on day 6 in $1 \mathrm{MSK} 5\left(7.65 \log _{10} \mathrm{CFU} \mathrm{ml}{ }^{-1}\right.$ ) (Figure 2B). These values were not significantly different to pure BSc203 $(p \leq 0.068)$. On day 22 , the BSc203 cell concentration in all mixed fermentations assayed was not significantly different to pure BSc203, except for co-culture 1MSK4 (Figure 2A). The BSc203 cell concentration in 1MSK4 was $1.38 \log _{10}$ cycle lower than in a pure BSc203 culture (negative interference). In the present study, a correlation between the decrease in BSc203cell growth in 1MKT4 and the high cell concentration of RCKT4 (6-7 $\log _{10} \mathrm{CFU} \mathrm{ml}{ }^{-1}$ during 12 days) was observed (Figure 2A). Several researchers have reported that other non-Saccharomyces yeast strains such as Pichia anomala and Hanseniaspora guilliermondii (Rojas et al., 2003) also decreased the final cell density of $S$. cerevisiae in mixed cultures, which is in agreement with our results.

This article is protected by copyright. All rights reserved. 
On day 22, in pure cultures, RCKT4 and RCKT5 produced significantly lower ethanol concentrations (7.91 and 6.05\%v/v, respectively) than BSc203 (12.81\%v/v) (Table 3). RCKT4 and RCKT5 presented a residual sugar concentration of $22.59 \mathrm{~g}^{-1}$ and $29.97 \mathrm{~g}^{-1}$, respectively, whereas BSc203 completed the fermentation (residual sugar $1.91 \mathrm{~g} \mathrm{l}^{-1}$ ). The sugar consumption rate of BSc203 during the first three days (16g $1^{-1}$ of sugar consumed) was significantly higher than that of RCKT4 and RCKT5 (6.5 and $6 \mathrm{~g} \mathrm{l}^{-1}$, respectively) $(p \leq 0.05)$. As expected, all multistarter cultures with RCKT4 and RCKT5 (Table 3) showed ethanol values that were not significantly different to those produced by pure BSc203, ranging from 12.81 to $12.92 \% \mathrm{v} / \mathrm{v}$, except for $1 \mathrm{MSK} 4$. In the latter fermentation, the amounts of ethanol and $\mathrm{CO}_{2}$ produced were significantly lower than in pure $\mathrm{BSc} 203$ and the other mixed cultures assayed $(p \leq 0.05)$. Similarly, Gobbi et al. (2013) reported that ethanol production in a mixed fermentation $90 \%$ L.t:10\%S.c was significantly lower than in S. cerevisiae used as control. Fermentations in all mixed cultures assayed were completed (residual sugar $\leq 1.96 \mathrm{~g} \mathrm{l}^{-1}$ ) except for 1MSK4 that presented $8.94 \mathrm{~g}^{-1}$ of residual sugar.

Mixed cultures with $L$. thermotolerans presented values for total acidity, volatile acidity and $\mathrm{pH}$ that were not significantly different to those in a pure culture of BSc203 $(p \leq 0.05)$, except for 1MSK5. In the latter culture, total acidity in wines increased $27.65 \%$ and acetic acid reduced 28.57\% compared with pure BSc203 culture (Table 3). In agreement with these results, other studies showed that L.t/S.c associations significantly affected positively the final wine composition by enhancing total acidity and reducing the $\mathrm{pH}$ (Kapsopoulou et al., 2007) and volatile acidity (Comitini et al., 2011). The oenological industry shows great interest in correcting insufficient acidity (Kapsopoulou et al., 2007) and high volatile acidity (Schutz and Gafner, 1993) of some grape musts from warm regions as San Juan and Mendoza (Argentina).

This article is protected by copyright. All rights reserved. 
These data suggests that at high initial concentrations, RCKT5 is a good candidate for used as biofungicide in wine grapes, because this strain did not affect the $S$. cerevisiae growth and the wine quality. With respect to RCKT4 interfered negatively on fermentative process, especially on $S$. cerevisiae growth and on the ethanol production.

\section{MATERIALS AND METHODS}

\section{Yeast strains}

Biocontrol yeasts: L. thermotolerans RCKT4 and RCKT5 were isolated from the grape surfaces from vineyards in Mendoza province, Argentina (Ponsone et al., 2011; 2016).

Oenological yeast: S. cerevisiae BSc203 was isolated from fermentation grape must in San Juan province, Argentina. This yeast has proven good fermentative characteristics (Vazquez et al., 2014).

Both the biocontrol strains and BSc203 were identified by restriction fragment length polymorphism (RFLP) (Ponsone et al., 2011; Nally et al., 2012).

\section{Media}

YEPD-agar: $10 \mathrm{~g}^{-1}$ Yeast Extract, $20 \mathrm{~g} \mathrm{l}^{-1}$ Peptone, $20 \mathrm{~g}^{-1}$ Dextrose, $20 \mathrm{~g} \mathrm{l}^{-1}$ agar. YEPD-MB-Phosphate Citrate Buffer-agar: $10 \mathrm{~g} \mathrm{l}^{-1}$ Yeast Extract, $20 \mathrm{~g} \mathrm{l}^{-1}$ Peptone, $20 \mathrm{~g} \mathrm{l}^{-1}$ Dextrose, $0.01 \%$ Methylene Blue, 0.1M Phosphate Citrate Buffer, 20g $1^{-1}$ agar.

CAS-HDTMA-PIPES-YNB-Glucose-agar: 60.5 $\mathrm{mg}^{-1}$ CAS (Chrome Azurol S), 72.9mg 1 ${ }^{-1}$ HDTMA (Hexadecyltrimethylammonium Bromide), 30.24g l $^{-1}$ PIPES (Piperazine-1,4-bis(2ethanesulfonic acid)), $6.7 \mathrm{~g} \mathrm{l}^{-1} \mathrm{YNB}, 1 \mathrm{mmol} \mathrm{l}^{-1} \mathrm{FeCl}_{3} \cdot 6 \mathrm{H}_{2} \mathrm{O}$ in $10 \mathrm{mmol}^{-1} \mathrm{HCl}, 20 \mathrm{~g} \mathrm{l}^{-1}$ glucose, $20 \mathrm{~g} 1^{-1}$ agar.

This article is protected by copyright. All rights reserved. 


\section{Characterization of $L$. thermotolerans-based biocontrol agents}

\section{Nutritional profiles: NOI and NS}

Biocontrol yeasts and BSc203 aliquots $\left(20 \mu \mathrm{L}, 10^{6} \mathrm{cells} \mathrm{ml}^{-1}\right)$ were inoculated on plates. Each plate contained one carbonate source $(10 \mathrm{mM})$, YNB with $20 \mathrm{~g}^{-1}$ agar, $\mathrm{pH} 5.5$. The carbonate sources assayed are present in wine grapes and represent the niche size: proline, asparagine, alanine, glutamic acid, tyrosine, arginine, lysine, methionine, glycine, malic acid, tartaric acid, fructose, melibiose, raffinose, rhamnose, sucrose and glucose. Plates were incubated at $25^{\circ} \mathrm{C}$ for 14 days. NOI were evaluated as the ratio between the number of carbonate sources used in common (biocontrol agent and BSc203) and the total number of carbonate sources utilized only by BSc203. NOI values of $>0.9$ represent competence between yeasts while scores of $<0.9$ represent occupation of separate niches. NS values were evaluated as the ratio between number of compounds used by each of the yeasts and number of compounds assayed in total (Collazo et al., 2017).

\section{Oenological behavior of the biocontrol yeasts. Tolerance to $\mathrm{S0}_{2}$, ethanol and sugar concentrations}

Yeast tolerance towards $\mathrm{SO}_{2}$, ethanol and sugar was assayed according to slightly modified methods described by Parish and Carrol (1987). $\mathrm{SO}_{2}$ concentrations evaluated in the present study were $0,25,50,75,100,150,200,250,300,400 \mathrm{mg} \mathrm{l}^{-1}$ and added to YNB plus $10 \mathrm{~g}^{-1}$ of glucose medium (pH3.5). The ability to start fermentations at 7, 8, 9, 10, 11 and 12\%v/v of ethanol was determined similarly. Tubes only containing YNB medium without glucose were used as negative controls.

Strain resistance to osmotic-stress was examined by winemaking tests using commercial concentrated grape must from $V$. vinifera $\mathrm{L}$. adjusted to $21^{\circ}$ Brix and $30^{\circ}$ Brix. The grape juice

This article is protected by copyright. All rights reserved. 
obtained was pasteurized for $30 \mathrm{~min}$ at $80^{\circ} \mathrm{C}$. This process did not produce caramelization of the grape juice following the Maillard reaction (Bozkurt et al., 1999).

All assays were carried out in $20 \mathrm{ml}$ tubes with $5 \mathrm{ml}$ of medium, and tubes were inoculated with $10^{6}$ cells $\mathrm{ml}^{-1}$. All microfermentations were checked for $\mathrm{CO}_{2}$ production and considered positive when, after a $3 \mathrm{~d}$ incubation period at $25^{\circ} \mathrm{C}$, Dürham bells located in the tubes were filled up for at least one-third of their capacity (Ubeda et al., 1995). The results are expressed as + (ability to ferment) and - (not ability to ferment). S. cerevisiae BSc203 was used as positive control.

\section{Influence of $L$. thermotolerans strains on S. cerevisiae growth during fermentative} process

Commercial must from $V$. vinifera $\mathrm{L}$. was pasteurized as above mentioned. The initial grape must composition was $22^{\circ}$ Brix and the $\mathrm{pH}$ 3.5. Biocontrol strains and $\mathrm{BSc} 203$ were preadapted in the same must at $13^{\circ} \mathrm{Brix}$ and $\mathrm{pH} 3.5$, during $12 \mathrm{~h}$ at $22^{\circ} \mathrm{C}$. Microvinifications were carried out in 51 glass flasks with 31 of pasteurized commercial must, and topped with Müller valves (Ciani and Rossini, 1987). The following mixed cultures were assayed:

1MSK4:1\%BSc203/99\% RCKT4; 1MSK5:1\%BSc203/99\%RCKT5;

2MSK4:50\%BSc203/50\%RCKT4; 2MSK5:50\%BSc203/50\%RCKT5;

3MSK4:99\%BSc203/1\%RCKT4; 3MSK5:99\%BSc203/1\%L. RCKT5. Pure and mixed cultures were inoculated at an initial concentration of $10^{6}$ cells $\mathrm{ml}^{-1}$ and were incubated at $18^{\circ} \mathrm{C}$. Pasteurized non-inoculated must was used as negative control under the same assay conditions. Fermentations under static conditions were monitored for $\mathrm{CO}_{2}$ release measuring weight loss every $24 \mathrm{~h}$ until the end of the fermentation (constant weight). The sugar consumption rate was calculated as the amount of sugar consumed $\left(\mathrm{g} \mathrm{l}^{-1}\right)$ in $72 \mathrm{~h}$.

This article is protected by copyright. All rights reserved. 
Fermentation samples were withdrawn every $24 \mathrm{~h}$ and spread on Wallerstein Laboratory Nutrient (WLN). This medium allows putative identification of yeasts according to color of the colonies. On WLN, BSc203 present creamy colonies, whereas RCKT4 and RCKT5 lightgreen colonies (Vazquez et al., 2014). At the end of the assay, fermented products were centrifuged at $11,000 \mathrm{xg}\left(10 \mathrm{~min}, 4^{\circ} \mathrm{C}\right)$, filtered and stored at $4^{\circ} \mathrm{C}$ until further analysis. The most important wine quality parameters (ethanol, volatile acidity, total acidity, $\mathrm{pH}$, residual sugar) were analyzed according to the official methods of the OIV (2013) and INV (2015).

\section{Statistical analysis}

In all the assays, three replicates per treatment were performed and the experiment was repeated twice.

To evaluate the effects of $L$. thermotolerans strains on BSc203 growth and on the wine quality, single-factor variance analysis (ANOVA) was carried out after verification of variance homogeneity (Levene test, $p \leq 0.05$ ). Significant differences were determined using Tukey's Test. SPSS version 21.0 (Chicago I. L.) was used.

\section{ACKNOWLEDGMENTS}

The authors gratefully acknowledge the support of this study by the PIO-CONICET, Argentina. We also would like to thank Dr. Juan Aguilera Sammaritano for his collaboration in the design of the figures and tables.

\section{CONFLICT OF INTERESTS}

The authors declare no conflicts of interest.

This article is protected by copyright. All rights reserved. 


\section{REFERENCES}

-Balikci, E. K., Tanguler, H., Jolly, N. P., \& Erten, H. (2016). Influence of Lachancea thermotolerans on cv. Emir wine fermentation. Yeast 33,313-321.

-Benito, Á., Calderón, F., Palomero, F., \& Benito, S. (2015). Combine Use of Selected Schizosaccharomyces pombe and Lachancea thermotolerans Yeast Strains as an Alternative to the Traditional Malolactic Fermentation in Red Wine Production. Molecules 20,95109523.

-Benito, Á., Calderón, F., \& Benito, S. (2017). The Combined Use of Schizosaccharomyces pombe and Lachancea thermotolerans_-Effect on the Anthocyanin Wine Composition.

Molecules 22, 739.

-Bisson, L. F. (1999). Stuck and sluggish fermentations. Am J Enol Vitic 50,107-119. -Bozkurt, H., Göğüş, F. and Erena, S. (1999). Nonenzymic browning reactions in boiled grape juice and its models during storage. Food Chem 64,89-93.

-Cabras, R. and Angioni, A. (2000). Pesticide residues in grapes, wines and their processing products. J Agric Food Chem 48,967-973.

-Calvo-Garrido, C., Elmer, P. A. G., Viñas, I., Usall, J., Bartra, E. and Teixidó, N. (2013). Biological control of botrytis bunch rot in organic wine grapes with the yeast antagonist Candida sake CPA-1. Plant Pathol 62,510-519.

-Ciani, M., Beco, L. and Comitini, F. (2006). Fermentation behaviour and metabolic interactions of multistarter wine yeast fermentations. Int J Food Microbiol 108,239-245.

-Ciani, M. and Rosini, G. (1987). The determination of alcohol capacity of wine making yeast. Annali Facolta`di Agraria Universita`di Perugia 41,753-762.

-Collazo, C., Abadias, M., Aguiló-Aguayo, I., Alegre, I., Chenoll, E. and Viñas, I. (2017). Studies on the biocontrol mechanisms of Pseudomonas graminis strain CPA-7 against foodborne pathogens in vitro and on fresh-cut melon. LWT Food Sci. Technol. 85,301-308.

This article is protected by copyright. All rights reserved. 
-Comitini, F., Gobbi, M., Domizio, P., Romani, C., Lencioni, L., Mannazzu, I. and Ciani, M. (2011). Selected non-Saccharomyces wine yeasts in controlled multistarter fermentations with Saccharomyces cerevisiae. Food Microbiol 28,873-882.

-Covarelli, L., Beccari, G., Marini, A. and Tosi, L. (2012). A review on the occurrence and control of ochratoxigenic fungal species and ochratoxin A in dehydrated grapes, non-fortified dessert wines and dried vine fruit in the Mediterranean area. Food Control 26,347-356.

-Escribano R, González-Arenzana L, Portu J, Garijo P, López-Alfaro I, López R, Santamaría P, Gutiérrez AR (2018). Wine aromatic compound production and fermentative behavior within different non-Saccharomyces species and clones. J Appl Microbiol. In press. -Fleet, G. H. and Heard, G. M. (1992). Yeasts-Growth during fermentation. In:Wine Microbiology and Biotechnology. G. H. Fleet (Ed.). Harwood Academic Publishers, Australia. pp27-54

-Gobbi, M., Comitini, F., Domizio, P., Romani, C., Lencionib, L., Mannazzud, I. and Ciani, M. (2013). Lachancea thermotolerans and Saccharomyces cerevisiae in simultaneous and sequential co-fermentation: A strategy to enhance acidity and improve the overall quality of wine. Food Microbiol 33,271-281.

-Guzzon, R., Franciosi, E. and Larcher, R. (2014). A new resource from traditional wines: characterisation of the microbiota of "Vino Santo" grapes as a biocontrol agent against Botrytis cinerea. Eur Food Res Technol 239,117-126.

-Henderson, C. M. and Block, D. E. (2014). Examining the role of membrane lipid composition in determining the ethanol tolerance of Saccharomyces cerevisiae. Appl Environ Microbiol 80:2966-72.

-INV-Instituto Nacional de Vitivinicultura (Argentina) (2015). http://www.inv.gov.ar -Janisiewicz, W. (1996). Ecological diversity, niche overlap, and coexistence of antagonists used in developing mixtures for biocontrol of postharvest diseases of apples. Phytopathol 
$86,473-479$.

- Jaspers, E. and Overmann, J. (2004). Ecological significance of microdiversity: identical 16S rRNA gene sequences can be found in bacteria with highly divergent genomes and ecophysiologies. Appl Environ Microbiol 70,4831-4839.

-Kapsopoulou, K., Kapaklis, A. and Spyropoulos, H. (2005). Growth and fermentation characteristics of a strain of the wine yeast Kluyveromyces thermotolerans isolated in Greece. World J Microbiol Biotechnol 21,1599-1602.

-Kapsopoulou, K., Mourtzini, A., Anthoulas, M. and Nerantzis, E. (2007). Biological acidification during grape must fermentation using mixed cultures of Kluyveromyces thermotolerans and Saccharomyces cerevisiae. World J Microbiol Biotechnol 23,735-739.

-Komárek, M., Cadková, E., Chrastný, V., Bordas, F., and Bollinger, J. C. (2010). Contamination of vineyard soils with fungicides: a review of environmental and toxicological aspects. Environ Int 36,138-151.

-La Penna, M., Nesci, A. and Etcheverry, M. (2004). In vitro studies on the potential for biological control on Aspergillus section Flavi by Kluyveromyces spp. Lett Appl Microbiol $38,257-264$.

-Leroch, M., Kretschmer, M. and Hahn, M. (2011). Fungicide resistance phenotypes of Botrytis cinerea isolates from commercial vineyards in South West Germany. J Phytopathol $159,63-65$

-Nadai, C., Treu, L., Campanaro, S., Giacomini, A. and Corich, V. (2016). Different mechanisms of resistance modulate sulfite tolerance in wine yeasts. Appl Microbiol Biotechnol 2,797-813.

-Nally, M. C., Pesce, V. M., Maturano, Y. P., Muñoz, C. J., Combina, M., Toro, M. E., Castellanos de Figueroa, L. I. and Vazquez, F. (2012). Biocontrol of Botrytis cinerea in table grapes by non-pathogenic Saccharomyces cerevisiae autochthonous yeasts from viticultural

This article is protected by copyright. All rights reserved. 
environments (San Juan, Argentina). Post Biol Technol 64,40-48.

-Nally, M. C., Pesce, V. M., Maturano, Y. P., Toro, M. E., Combina, M., Castellanos de Figueroa, L. I. and Vazquez, F. (2013). Biocontrol of fungi isolated from sour rot infected table grapes by Saccharomyces and other yeast species. Post Biol Technol 86,456-462. -Nally, M.C., Pesce, V.M., Maturano, Y.P., Rodriguez, Assaf, L.A., Toro, M.E., Castellanos de Figueroa, L.I. and Vazquez, F. (2015). Antifungal modes of action of Saccharomyces and other biocontrol yeasts against fungi isolated from sour and grey rots. Int J Food Microbiol 204,91-100.

-Nesci, A., Romina, V., Bluma, V. and Etcheverry, M. G. (2005). In vitro selection of maize rhizobacteria to study potential biological control of Aspergillus section Flavi and aflatoxin production. Eur J Plant Pathol 113,159-171.

-OIV (Organization International of Vine and Wine) (2013). http://www.oiv.int -Parish, M. E. and Carroll, D. (1987). Fermentation characteristics of Saccharomyces cerevisiae isolates from Vitis rotundifolia grapes and musts. Am J Enol Vitic 38,45-48.

- Ponsone, M. L., Chiotta, M. L., Combina, M., Dalcero, A. and Chulze, S. (2011).

Biocontrol as a strategy to reduce the impact of ochratoxin A and Aspergillus section Nigri in grapes. Int J Food Microbiol 151,70-77.

-Ponsone, M. L., Nally, M. C., Chiotta, M. L., Combina, M., Köhl, J. and Chulze, S. N. (2016). Evaluation of the effectiveness of potential biocontrol yeasts against black sur rot and ochratoxin A occurring under greenhouse and field grape production conditions. Biol Control $103,78-85$

-Rojas, V., Gil, J. V., Piñaga, F. and Manzanares, P. (2003). Acetate ester formation in wine by mixed cultures in laboratory fermentations. Int J Food Microbiol 86,181-188. -Schutz, M. and Gafner, J. (1993). Analysis of yeast diversity during spontaneous and induced alcoholic fermentations. J Appl Bact 75,551-558.

This article is protected by copyright. All rights reserved. 
-Stanley, G.A., Douglas, N.G., Every, E.J. Tzanatos, T. and Pamment, N.B. Inhibition and stimulation of yeast growth by acetaldehyde. Biotechnol Lett 15, 1199-1200.

-Ubeda, J., Briones, A. I., lzquierdo, P. and Palop, L. I. (1995). Predominant Saccharomyces cerevisiae strains in the fermentation of Air on Grape Musts with $\mathrm{SO}_{2}$ Lebensm.-Wiss. u.-

Technol 28,584-588.

-Vazquez, F., Maturano, Y. P. and Nally, M. C. (2014). Interacciones levadura- levadura y levadura - hongos filamentosos para una vitivinicultura sustentable. XII. Congreso Argentino de Micología; XXII Jornadas Argentina de Micología, $1^{\circ}$ Reunión de la asociación Micológica Carlos Spegazzini. Argentina.

This article is protected by copyright. All rights reserved. 
Table 1. Nutritional profile analysis of L. thermotolerans yeasts and BSc203.

\begin{tabular}{|c|c|c|c|c|}
\hline \multirow{2}{*}{\multicolumn{2}{|c|}{ Nutritional sources }} & \multicolumn{2}{|c|}{ L. thermotolerans } & \multirow{3}{*}{$\frac{\text { BSc203 }}{+}$} \\
\hline & & \multirow{2}{*}{$\begin{array}{c}\text { RCKT4 } \\
-\end{array}$} & \multirow{2}{*}{$\begin{array}{c}\text { RCKT5 } \\
-\end{array}$} & \\
\hline \multirow{8}{*}{ 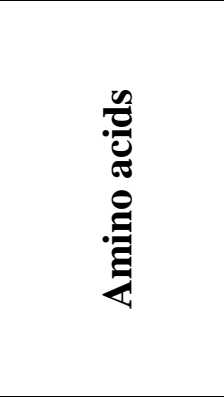 } & Proline & & & \\
\hline & Lysine & - & - & - \\
\hline & Arginine & + & + & + \\
\hline & Asparagine & - & - & + \\
\hline & Alanine & - & - & + \\
\hline & Glycine & - & - & - \\
\hline & Methionine & - & - & - \\
\hline & Tyrosine & - & - & - \\
\hline \multirow{3}{*}{ ప్రై } & Glutamic acid & - & - & - \\
\hline & Malic acid & - & - & - \\
\hline & Tartaric acid & - & - & - \\
\hline \multirow{6}{*}{ 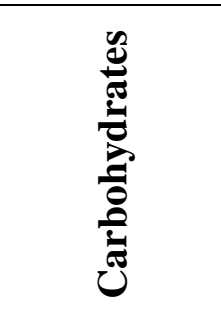 } & Fructose & - & - & + \\
\hline & Glucose & + & + & + \\
\hline & Sucrose & + & + & + \\
\hline & Raffinose & + & + & + \\
\hline & Rhamnose & - & - & - \\
\hline & Melibiose & - & - & + \\
\hline \multirow{2}{*}{$\begin{array}{l}\text { Nutritional } \\
\text { Ecology }\end{array}$} & $N S$ & $4 / 16=0.25$ & $4 / 16=0.25$ & $9 / 16=0.56$ \\
\hline & NOI & $4 / 9=0.44$ & $4 / 9=0.44$ & \\
\hline
\end{tabular}

\section{REFERENCES:}

$-=$ Not assimilate carbonate source, $+=$ Assimilate carbonate source .

This article is protected by copyright. All rights reserved. 
Table 2. Tolerance of biocontrol yeasts to different concentrations of the ethanol (7-12\% v/v), sulfur dioxide (25-400 $\left.\mathrm{mg}^{-1}\right)$ and sugar (21 and $30{ }^{\circ}$ Brix).

\begin{tabular}{|c|c|c|c|c|}
\hline 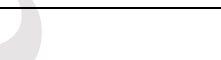 & Treatments & & ast strain & \\
\hline & & RCKT4 & RCKT5 & BSc203 \\
\hline & $25 \mathrm{mg} \mathrm{l}^{-1} *$ & + & + & + \\
\hline & $50 \mathrm{mg} \mathrm{l}^{-1} *$ & + & + & + \\
\hline & $75 \mathrm{mg} \mathrm{l}^{-1} *$ & + & + & + \\
\hline & $100 \mathrm{mg} \mathrm{l}^{-1 *}$ & + & + & + \\
\hline $\mathrm{SO}_{2}$ & $150 \mathrm{mg} \mathrm{l}^{-1} *$ & + & + & + \\
\hline & $200 \mathrm{mg} \mathrm{l}^{-1} *$ & + & + & + \\
\hline & $250 \mathrm{mg} \mathrm{l}^{-1} *$ & + & + & + \\
\hline & $300 \mathrm{mg} \mathrm{l}^{-1} *$ & - & - & + \\
\hline & $400 \mathrm{mg} \mathrm{l}^{-1} *$ & - & - & + \\
\hline & & & & \\
\hline & $7 \% \mathrm{v} / \mathrm{v}^{*}$ & + & + & + \\
\hline & $8 \% \mathrm{v} / \mathrm{v}^{*}$ & + & + & + \\
\hline Ethanol & $9 \% \mathrm{v} / \mathrm{v}^{*}$ & + & + & + \\
\hline & $10 \% \mathrm{v} / \mathrm{v} *$ & + & + & + \\
\hline & $11 \% \mathrm{v} / \mathrm{v} *$ & + & + & + \\
\hline & $12 \% \mathrm{v} / \mathrm{v} *$ & - & - & + \\
\hline Grape must & $21^{\circ}$ Brix & + & + & + \\
\hline & $30^{\circ}$ Brix & + & + & + \\
\hline
\end{tabular}

\section{REFERENCES:}

+: ability to ferment, -: not ability to ferment

* in YNB+glucose

This article is protected by copyright. All rights reserved. 
Table 3. Influence of L. thermotolerans strains on the analytical profile of wines in pure and mixed cultures with BSc203. Values followed by the same letter in the same column were not significantly different at $p \leq 0.05$.

\begin{tabular}{|c|c|c|c|c|c|c|}
\hline Cultures & $\begin{array}{c}\text { Sugar } \\
\text { consumption } \\
\text { rate in } 72 \mathrm{~h} \\
\left(\mathrm{~g} \mathrm{I}^{-1}\right)\end{array}$ & $\begin{array}{c}\text { Ethanol } \\
\left(\mathrm{g} \mathrm{l}^{-1}\right)\end{array}$ & $\begin{array}{c}\text { Total acidity } \\
\left(\mathrm{g} \mathrm{I}^{-1}\right)\end{array}$ & $\begin{array}{l}\text { Volatile acidity } \\
\qquad\left(\mathrm{g} \mathrm{l}^{-1}\right)\end{array}$ & $\begin{array}{c}\text { Residual sugar } \\
\left(\mathrm{g} \mathrm{l}^{-1}\right)\end{array}$ & pH \\
\hline Pure BSc203 & $16 \pm 0.01^{\mathrm{a}}$ & $12.81 \pm 0.21^{\mathrm{a}}$ & $5.17 \pm 0.12^{\mathrm{a}}$ & $0.56 \pm 0.02^{\mathrm{a}}$ & $1.91 \pm 0.11^{\mathrm{a}}$ & $3.39 \pm 0.01^{2}$ \\
\hline 3MSK4 & $15.2 \pm 0.4^{\mathrm{ab}}$ & $12.75 \pm 0.16^{\mathrm{a}}$ & $5.19 \pm 0.13^{\mathrm{a}}$ & $0.58 \pm 0.03^{\mathrm{a}}$ & $1.9 \pm 0.11^{\mathrm{a}}$ & $3.38 \pm 0.01^{2}$ \\
\hline 2MSK4 & $15.3 \pm 0.034^{\mathrm{ab}}$ & $12.83 \pm 0.05^{\mathrm{a}}$ & $5.21 \pm 0.21^{\mathrm{a}}$ & $0.53 \pm 0.06^{\mathrm{a}}$ & $1.88 \pm 0.03^{\mathrm{a}}$ & $3.38 \pm 0.02^{\mathrm{a}}$ \\
\hline 1MSK4 & $14.7 \pm 0.05^{\mathrm{ab}}$ & $11.01 \pm 0.03^{b}$ & $5.28 \pm 0.3^{\mathrm{a}}$ & $0.5 \pm 0.09^{\mathrm{a}}$ & $8.94 \pm 0.11^{b}$ & $3.37 \pm 0.02^{\mathrm{a}}$ \\
\hline 3MSK5 & $15.8 \pm 0.031^{\mathrm{a}}$ & $12.83 \pm 0.08^{\mathrm{a}}$ & $5.36 \pm 0.11^{\mathrm{a}}$ & $0.55 \pm 0.02^{\mathrm{a}}$ & $1.61 \pm 0.14^{\mathrm{a}}$ & $3.39 \pm 0.02^{\mathrm{a}}$ \\
\hline 2MSK5 & $14.5 \pm 0.02^{\mathrm{ab}}$ & $12.71 \pm 0.06^{\mathrm{a}}$ & $5.45 \pm 0.06^{\mathrm{a}}$ & $0.5 \pm 0.02^{\mathrm{a}}$ & $1.82 \pm 0.18^{\mathrm{a}}$ & $3.37 \pm 0.03^{a}$ \\
\hline 1MSK5 & $15.1 \pm 0.03^{\mathrm{a}}$ & $12.92 \pm 0.04^{\mathrm{a}}$ & $6.6 \pm 0.13^{b}$ & $0.40 \pm 0.03^{b}$ & $1.96 \pm 0.02^{\mathrm{a}}$ & $3.35 \pm 0.01^{\mathrm{b}}$ \\
\hline Pure RCKT4 & $6.5 \pm 0.04^{b}$ & $7.91 \pm 0.41^{\mathrm{c}}$ & $6.66 \pm 0.15^{b}$ & $0.39 \pm 0.01^{\mathrm{c}}$ & $22.59 \pm 2.01^{\mathrm{c}}$ & $3.34 \pm 0.02^{b}$ \\
\hline Pure RCKT5 & $6 \pm 0.07^{c}$ & $6.05 \pm 0.09^{\mathrm{d}}$ & $9.43 \pm 0.4^{\mathrm{c}}$ & $0.26 \pm 0.05^{d}$ & $29.27 \pm 2.18^{d}$ & $3.32 \pm 0.02^{b}$ \\
\hline
\end{tabular}

\section{REFERENCES:}

1MSK4:1\%S.c/99\%RCKT4; 2MSK4:50\%S.c/50\%RCKT4; 3MSK4:99\%S.c/1\%RCKT4.

1MSK5:1\%S.c/99\%RCKT5; 2MSK5:50\%S.c/50\%RCKT5; 3MSK5:99\%S.c/1\%RCKT5.

This article is protected by copyright. All rights reserved. 
Figure 1. Population dynamics of RCKT4 and RCKT5 in pure and mixed cultures with BSc203 (3MSK4, 2MSK4, 1MSK4 [A] and 3MSK5, 2MSK5, 1MSK5 [B]). The data are presented as the average of three independent experiments. References: $\mathbf{A}:-100 \%$ RCKT4, $\rightarrow$ RCKT4 in 2MSK4 (50\%Sc-50\%RCT4), ${ }^{-}$RCKT4 in 3MSK4 (99\%Sc1\%RCKT4), $\stackrel{*}{*}$ RCKT4 in 1MSK4 (1\%Sc-99\%RCT4). B: $\bullet 100 \%$ RCKT5, ${ }^{-}$RCKT5 in 2MSK5 (50\%Sc-50\%RCKT5), ${ }^{-}$RCKT5 in 3MSK5 (99\%Sc1\%RCKT5), * RCKT5 in 1MSK5 (1\%Sc-99\%RCT5).

Figure 2. Population dynamics of BSc203 in pure and mixed cultures with RCKT4 (3MSK4, 2MSK4, 1MSK4) [A] and with RCKT5 (3MSK5, 2MSK5, 1MSK5) [B]. The data are presented as the average of three independent experiments. References: $\mathbf{A} \rightarrow-100 \%$ BSc203, $\rightarrow$ BSc203 in 2MSK4 (50\%Sc-50\%RCT4), $\rightarrow$ BSc203 in 3MSK4 (99\%Sc1\%RCKT4), ${ }^{-}$BSc203 in 1MSK4 (1\%Sc-99\%RCT4).

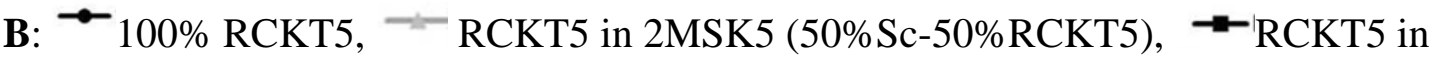
3MSK5 (99\%Sc-1\%RCKT5), ${ }^{-}$RCKT5 in 1MSK5 (1\%Sc-99\%RCT5).

This article is protected by copyright. All rights reserved. 

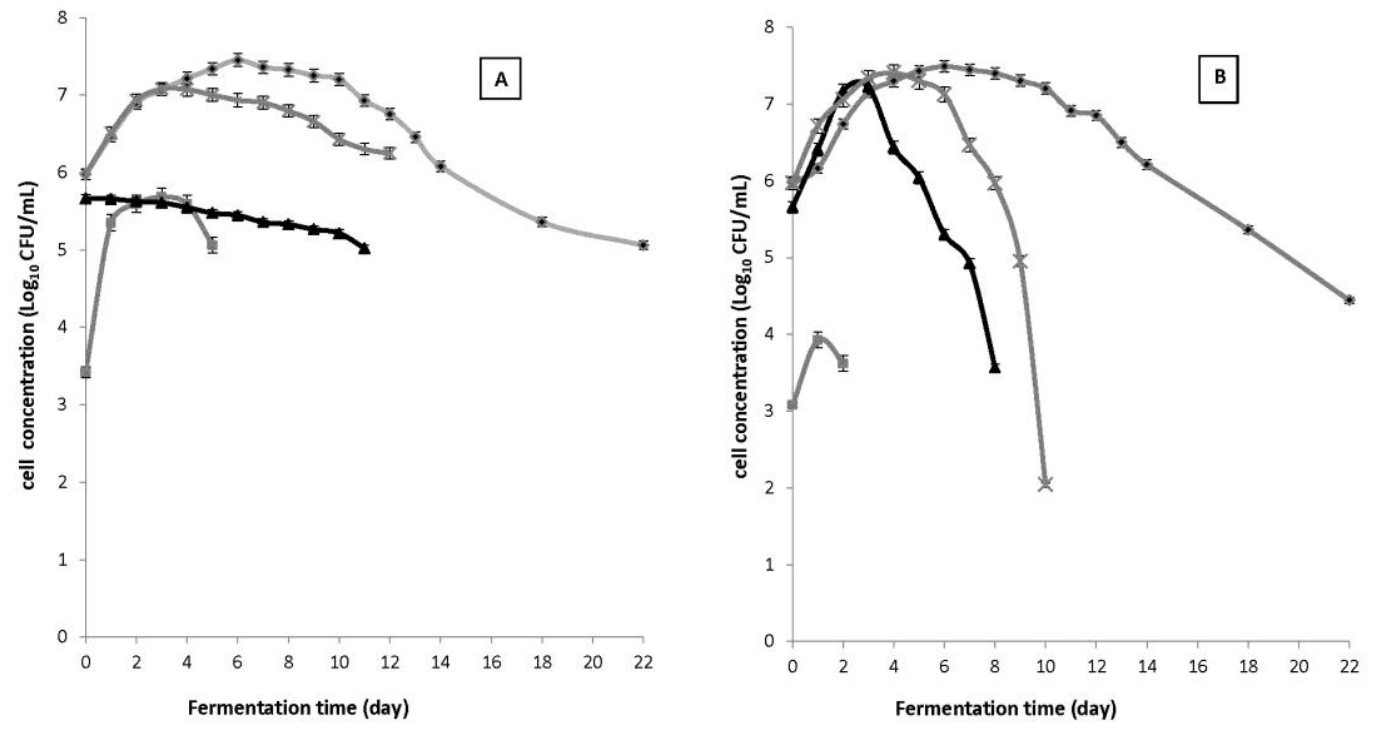

This article is protected by copyright. All rights reserved. 

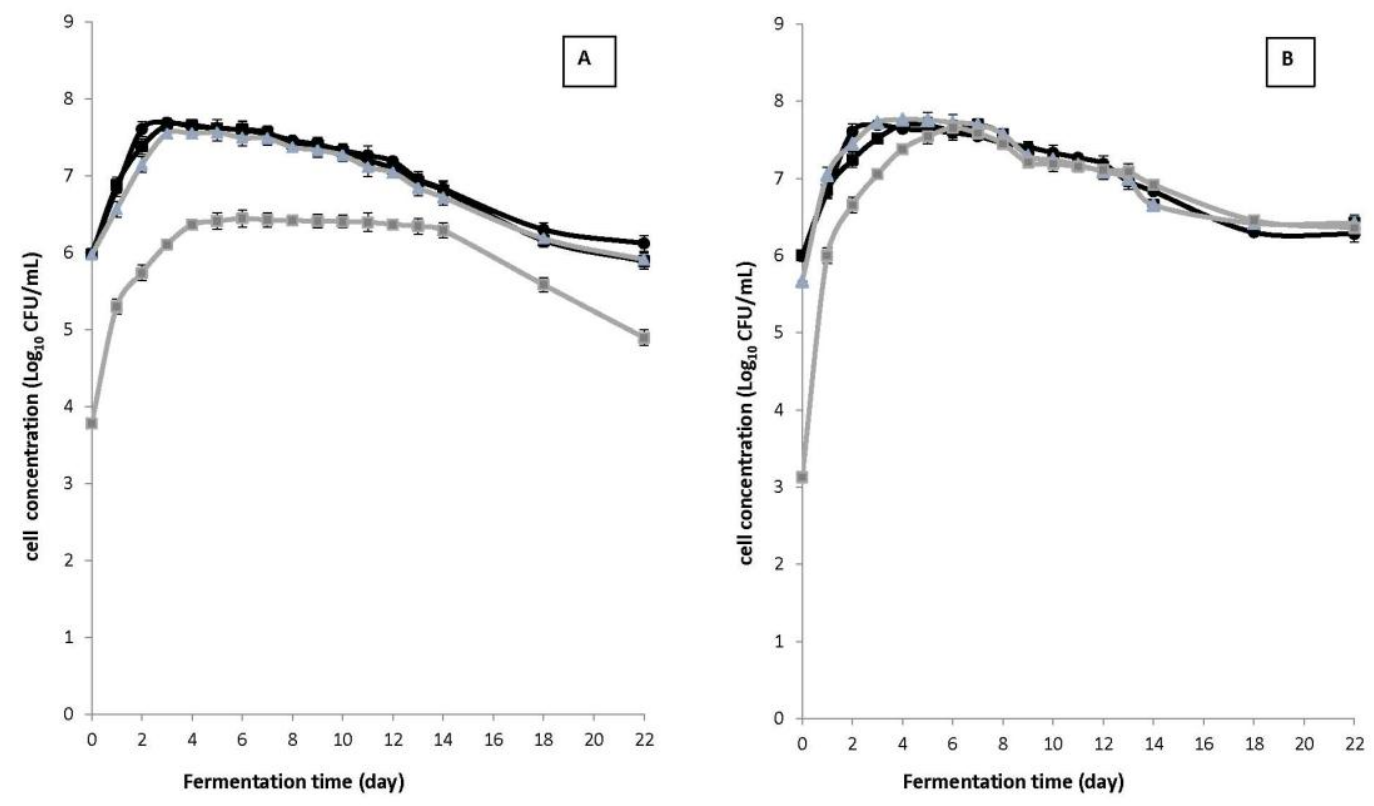

This article is protected by copyright. All rights reserved. 